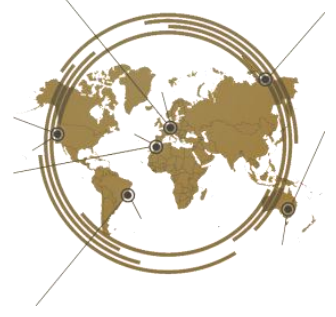

\title{
Difficulties in using correct English prepositions among EFL students
}

\author{
Ibrahim Abdalla* \\ Albahan University, Saudi Arabia
}

The objectives of this study are to find out the reasons of the problem related to using correct English prepositions and find some solutions. The participants were ten students at levels seven and eight, at the Faculty of Sciences and Arts. The researcher used the Descriptive Statistical Method and collected the data via a written test as the main research tool. The data were then analyzed quantitatively. The results were as follows: Saudi students faced problems with using the correct prepositions after certain verbs. Students encountered difficulties in identifying the correct prepositional phrase. Students experienced the same problem with the use of English prepositions in writing tasks and in daily communication. The recommendations of this study are that students need to revise the use of English prepositions in general and need more practice in the use of prepositions after certain verbs. They also need to make a greater effort to use English prepositional phrases in their written work. Regarding writing courses, students need to focus more on the use of prepositions in general. Curriculum designers need more attention about teaching prepositions in their textbooks and curriculums.

Keywords: First Language L1, Second Language L2, First Language, Second Language

OPEN ACCESS

ISSN 25033492 (online)

${ }^{*}$ Correspondence:

Ibrahim Abdalla

Ibrahimabdalla2006@gmail.com

Received: 23th May 2021 Accepted: 13th September 2021 Published: 14th September 2021

Citation:

Abdalla, I. (2021). Difficulties in Using Correct English Prepositions among EFL Students.

J. Eng. Educ. Society. 6:2. doi:10.21070/jees.v6i2.1640

\section{INTRODUCTION}

Learners of English as a Foreign Language (EFL) need to master four basic skills in English. Due to globalization and the increased use of English in education, communication, business and entertainment, correct writing and fluent communication in English are skills that are in high demand at present. Writing is the most difficult and complex skill for EFL learners to acquire. According to, Choudhury \& PGCTE (2013) he said, "the four-core language skill are listening, speaking, reading and writing where writing is obviously the most difficult skill for second and foreign language learners to master".(p.27). Saudi EFL learners experience problems with the use of correct prepositions because some of them do not exist in their first language (L1), which is Arabic. There are many reasons for the misuse of prepositions, one of which is the lack of practices them in curricula. Furthermore, many prepositions do not have rules governing their use, while others have different functions, which lead to problems with using them correctly. 
According to Lindstomberg (1991), Lorincs (2012), there are many reasons why prepositions are found to be difficult for English learners, some of these reasons relate to the properties of prepositions in English and to the difference between the properties of prepositions when compared to the learners L1. ( $p$ 225-236). Moreover, some prepositions collocate with verbs, nouns, and adjectives to convey various meanings, while the differences in the use, number, and meanings of prepositions in Arabic and English also lead to difficulties in finding the equivalence prepositions between the two languages. This study attempts to answer the following questions: 1- Do Saudi students as EFL use prepositions after certain verbs accurately? 2- Do Saudi students as EFL use prepositional phrases correctly? The following hypotheses are proposed: 1- Saudi students as EFL can identify the appropriate prepositions to use after certain verbs. 2- Saudi students as EFL use English prepositional phrases correctly. The significance of this study the researcher investigated the problems that occur when attempting to use English prepositions correctly in the hope that this would enable students to correct their mistakes and to pay attention to the accurate use of English prepositions, as well as to encourage students to practice using English prepositions. This study also fills the gap in previous studies that have concentrated on the use of specific prepositions in general terms.

While reviewing Saudi university students' tasks, the researcher noticed that the students experienced difficulties with using English prepositions, as the students made numerous mistakes in prepositional use in their written work and when communicating. Saudi students focus less on practicing the use of English prepositions in their communication and writing tasks.

Prepositions are words that are used before or after nouns or pronouns to show the relationship between them in the sentence. Many scholars and researchers have defined prepositions: Castro (2013) defined "prepositions as words that show the relationship between two words in a sentence". (p.97-108). Also, Seaton and Mew (2007, p. 132) define "preposition as a word that connects one thing with another, showing how they are related. They assert that it is usually followed by a noun or pronoun". (p.132). According to, Cowan (1983) stated "preposition as a group of word that indicates relationship between the object of preposition and some other words in the sentence". (p.281). In addition, o Yates (1999), "The word "preposition" has a straightforward definition: a word placed before a noun or pronoun to define its relationship with another word in the sentence.". (p.5).

Thus, a preposition is a part of speech that is placed before nouns or pronouns to indicate place, direction, source and so on, as well as to show the relationship of a noun or pronoun to other words in a sentence; as Wren and Martin (1999) stated, 'The preposition is a word placed before a noun or a pronoun to show in what relation the thing denoted by it stands in regarding something else' (p. 106). Another author, Riyanto (2012), described prepositions as follows: 'Prepositions are words that use with a noun or pronoun that are placed in front of them to show a relation between these words with another part of the sentence'. The English language has a vast number of prepositions that fall under different categories:

1. Place: I will go to London this week.

2. Time: I will be there at 7.00 O'clock.

3. Direction: After they arrived, Ali went to the north.

4. Agent: The lecture was studied by her.

5. Instrument: The plumber fixed the pipe with a hammer.

Moreover, prepositions can be categorized as simple or complex. Simple prepositions include 'in', 'on', 'at', 'for', 'off' and the like, while examples of complex prepositions are 'instead of', 'because of', 'as far as' and 'on behalf of'. According to Kofi (2010), 'English has 60 to 70 prepositions, a higher number than most other languages' (p.297). Furthermore, Stageberg (1981) stated that 'prepositions are words like of, in, on, at and to which are usually followed by a noun, noun phrase, personal pronoun, or noun substitute called the object of the preposition' ( $\mathrm{p}$. 169), while Huddleston (1984) stated that "prepositions are the subtlest and a set of small words that are of a closed class in the English language' (p. 336).

Walker (1982) considered that a 'preposition is a word that shows a relationship between a noun or pronoun and other parts of the sentence' (p. 123), while Wishon \& Burks $\underline{(1980)}$ add, "connective words that show the relationship between the nouns following them and one of the basic sentences elements: subject, verb, object, or complement." (p.285) the famed linguist Randolph (1985) stated that '[a] preposition expresses a relation between two entities, one being that represented by the prepositional complement' ( $p$. 673).

The current study focuses on prepositions that follow certain verbs (in, on, at, of, for and from), and on prepositional phrase such as 'from time to time', 'by air', 'by bus', 'concentrate on' and 'believe in'. In these compounds, the prepositions are linked into more than one word, but have a single function. As shown in Table 1, many verbs are followed by specific prepositions.

A prepositional phrase consists of a preposition followed by a complement to form a single constituent. The supplement can be a noun, a pronoun, or a clause. Prepositional phrases are used by English speakers in general and by EFL students in writing and daily communication. In Saudi schools, teachers ignore the teaching of prepositional phrases because the curricula do not touch on this aspect, and it is difficult to teach students the correct meanings. Thus, to allow EFL students to communicate confidently in English, prepositional phrases need to be taught appropriately at schools because EFL students are unable to grasp the meanings of prepositional phrases easily.

Saudi EFL students experience problems with the use of prepositional phrases because they have specific uses, as well as due to the differences between Arabic as the L1 and English as the L2. Many authors have defined the word 'phrase'; according to Biber (2003), '[a] phrase may consist of a single word or a group of words. 
Phrases can be identified by substitution that is, by replacing one expression with another, to see how it fits into the structure' (p. 38), and according to the researcher '[p]prepositional phrases mostly consist of a preposition followed by a noun phrase, known as prepositional complement. The preposition can be thought of as a link relating the noun phrase to preceding structures.
Similarly, Warriner (1958) stated that '[a] prepositional phrase is a group of words beginning with a preposition and ending with a noun or pronoun (P.211).

Forms of Prepositional Phrases

1. Preposition $+\operatorname{noun}(\mathrm{s})$ : at a hospital, from Saudi Arabia.

2. Preposition + pronoun(s): with her, for you and him.

3. Preposition + gerund(s): by swimming, for dancing.

4. Preposition + clause(s): about what Mona needs, the girls who love you.

5. Preposition + object: with her sister.

TABLE 1 | Shows Some Verbs Follow by Certain Prepositions

\begin{tabular}{|c|c|c|}
\hline $\begin{array}{c}\text { Verbs followed by specific } \\
\text { prepositions } \\
\text { from }\end{array}$ & $\begin{array}{c}\text { Verbs followed by specific } \\
\text { prepositions } \\
\text { to }\end{array}$ & $\begin{array}{c}\text { Verbs followed by specific } \\
\text { prepositions } \\
\text { off }\end{array}$ \\
\hline separate & listen & colour \\
\hline graduate & talk & school \\
\hline escape & reply & limits \\
\hline prohibit & $a d d$ & duty \\
\hline borrow & agree & work \\
\hline retire & object & site \\
\hline suffer & happen & the radar \\
\hline hinder & respond & the record \\
\hline prevent & talk & the wall \\
\hline infer & in & the shelf \\
\hline escape & persist & the map \\
\hline abstain & believe & the point \\
\hline protect & involve & insist on \\
\hline resign & participate & focus on \\
\hline recover & arrive & count on \\
\hline rescue & result & play \\
\hline stem & succeed & work \\
\hline save & specialise & congratulate \\
\hline hide & with & concentrate \\
\hline$o f$ & trust & for \\
\hline approve & help & excuse \\
\hline stream & comply & care \\
\hline stand & coincide & pray \\
\hline hear & confuse & pay \\
\hline hope & tamper & search \\
\hline remind & associated & which \\
\hline think & acquaint & long \\
\hline cure & deal & scold \\
\hline compose & cover & ask \\
\hline convict & confront & ready \\
\hline desire & compare & work \\
\hline Get tire & agree & wish \\
\hline about & discuss & wait \\
\hline dream & charge & vote \\
\hline concern & cluster & blame \\
\hline forget & $a t$ & ask \\
\hline
\end{tabular}




\begin{tabular}{ccc}
\hline know & point & apologies \\
think & look & apply \\
boast & aim & admire \\
care & peer & prepare \\
argue & smile & blame \\
worry & laugh & head \\
protest & stare & Fear \\
decide & glance & fine \\
\hline
\end{tabular}

TABLE 2 | Some Prepositional Phrases

\begin{tabular}{|c|c|c|}
\hline \multicolumn{3}{|c|}{ Some Prepositional Phrases } \\
\hline on & in & off \\
\hline call & the $21^{\text {st }}$ century & school \\
\hline business & particular & work \\
\hline the newspaper & the afternoon & air \\
\hline schedule & the evening & duty \\
\hline a diet & March & the record \\
\hline the record & decline & site \\
\hline The freeway & danger & the shelf \\
\hline credit & focus & the wall \\
\hline the beach & need of & the radar \\
\hline behalf of & the news & the record \\
\hline at & under & for \\
\hline issue & the ground & love \\
\hline hand & the bed & good \\
\hline First sight & the table & the benefit \\
\hline the outset & the bridge & the restof \\
\hline high speed & repair & hire \\
\hline large & stress & life \\
\hline last & arrest & the time being \\
\hline the end & suspicion & a good cause \\
\hline heart & pressure & certain \\
\hline midnight & by & nothing \\
\hline Out of & birth & the time being \\
\hline service & car & sale \\
\hline order & train & once \\
\hline context & bus & example \\
\hline doors & aeroplane & the moment \\
\hline duty & $\operatorname{taxi}$ & from \\
\hline data & force & experience \\
\hline reach & law & memory \\
\hline fashion & nature & now on \\
\hline control & mistake & time to time \\
\hline
\end{tabular}

\section{The Use of Prepositional Phrases}

1. A Prepositional Phrase used as an Adverb.

A prepositional phrase that modifies a verb, an adjective or an adverb is called an adverb phrase, and provides information about when, where, why, how, to what extent or how far. As Warriner (1958) stated, 'When a prepositional phrase tells when, where, how, how much, or how far the action of the verb takes place, then it is used as an adverb and is called an adverb phrase'. Examples are 'Ali usually swims in the swimming pool' and 'He travelled to London on foot'. 
The prepositional phrase that modifies a verb, adjective, or adverb is called an adverb phrase. It tells when, where, why, how, and to what extent or how far. John (1958) stated, "When a prepositional phrase tells when, where, how, how much, or how far the action of the verb takes place, then it is used as an adverb and is called an adverb phrase". Examples

(1) Ali usually swims in the swimming pool.

(2) He travelled to London on foot.

\section{Prepositional Phrases used as an Adjective.}

When an adjective is used to describe a noun or a pronoun, it can do so via a prepositional phrase, and answers questions pertaining to what kind or which one. For example, 'Ali from Makkah ate two green apples' and 'The cats on the rug are white'.

There are many previous studies and researchers have discussed prepositions in relation to EFL in different countries. Some examples are provided below. Ibrahim (2017), the study adopted a descriptive, analytical, and quasi-experimental method. The sample consisted of 40 students at Posha Academy in the first semester of the academic year 2017 - 2018. The researcher used a test as a tool to collect the data, which were analyzed using SPSS. The study's findings revealed that most of the students encountered problems when using prepositions of time and proposed the following recommendations: Curricula designers should pay more attention to prepositions when designing syllabuses. Teachers should provide students with intensive exercises including prepositions. Students should pay more attention to English in general and to prepositions. Teachers should employ effective teaching techniques to help students improve in this area.

Almahameed (2016), Jordan, the researchers used a test consisting of fifteen sentences in this study of a sample of 53 students in the first to fourth academic years that were majoring in the English language. The study's results showed that Jordanian learners of English encountered moderate difficulty in learning the three uses of prepositions; this difficulty was ascribed mainly to L1 interference as opposed to intralingual interference. The findings also revealed that the participants found prepositions of standard most difficult to learn, followed by prepositions of accompaniment and prepositions of possession.

Herdi and Andriana (2017), Indonesia. This research implemented a quantitative research design using a survey. The sample population was first-year students in the English Education Department, and the results of the study showed that the average score for the students' ability to use prepositions of direction was 66.47. In conclusion, the students' knowledge of using prepositions of direction was categorized as 'fair'.

Al-Aidroos et. al (2008), Shandi University -Sudan. "Error Analysis of the use of prepositions in English writing skill". The study applied analytical and descriptive method, the study population includes teachers and students English Language department at University of Shendi, Faculty of arts. The sample of the study includes 10 teachers and
28 students, the study tools are questionnaire and test. The researcher used the percentage for analyzing data and come up with the following results: these prepositions are problematic, students assume that prepositions are easy, and prepositions aren't given enough efforts in teaching, also recommendations come out as follow: prepositions should be included in the syllabus of the university, teachers should give enough effort for teaching prepositions and students should be motivated and be aware of learning prepositions.

Elkhadiri and Khouya (2019), University South Korea. The researchers used three tests for different tasks with a sample of 80 Moroccan third-year university students. The study's finding proved that Moroccan students experienced extreme difficulty with the use of the English locative, as they made many mistakes in their attempts to place the five targeted prepositions in the correct places. The research revealed that Standard Arabic could facilitate learning when the prepositional systems of English and Arabic shared some similarities.

Al-Yaari et. al (2013). Saudi Arabia. The researchers used a questionnaire to test the participants' ability to translate the English prepositions of time and place at, in and on. The sample consisted of 50 senior students of both sexes (25 males and 25 females) who were studying at the Department of English, College of Arts, King Saud University. The findings revealed that Saudi EFL students experienced problems related to use and usage when translating simple English prepositions into Arabic. There were also significant differences in the performances of males and females, as the females scored higher marks than did the males. These findings suggest that the acquired skills and abilities involved in translation appear to be more strongly activated in the English-Arabic tasks performed by women compared to men.

In summary, most of the studies conclude that there are problems with prepositional use in general. Most of the participants made mistakes when using prepositions of time, in, on and at. Moreover, they did not know the rules for using these prepositions correctly, and the numerous differences between English and Arabic prepositions led to much of the confusion and misuse. The present study fills the research gap in studies that have addressed the problems with using English prepositions by focusing on English prepositions of place and time.

\section{METHODS}

The researcher used the statistic analytic method in this study; a written test was used to collect the data, which were then analyzed via SPSS.

\section{Sample for the Study}

The sample for this study consisted of ten Saudi University students who were majoring in English Language at the English Department at Albaha University in Almandag, Saudi Arabia. 
The students were in levels seven and eight, were aged between twenty and twenty-two, and all of them spoke Arabic as the L1 and English as the L2.

\section{Instrument of the study}

The researcher used one tool, which was a written test, to collect the students' data. The test was divided into two parts: In part one, the students were given certain verbs and were required to write down the correct prepositions that followed them. In part two, the students were given certain verbs, nouns, and adjectives, and were required to write down the suitable prepositions to produce the correct prepositional phrase (see Appendix 1) for a sample of the written test). The researcher then corrected the tests according to the rules of English.

\section{Procedures}

The students given a test on two worksheets and asked to write down the prepositions that followed certain English verbs randomly in the first sheet (part one). Also, they were asked to write down the prepositions that follow certain prepositional phrases in the second worksheet (part two) please check appendix1. The researcher corrected the students' tests and analyzed the results via SPSS.

\section{Limitation of the Study}

This study was limited to ten students at the English Department in the Faculty of Sciences and Arts at Albaha University in Almandag. It took place during the first semester of the academic year 2020-2021.

\section{Data Analysis}

The data in this study were collected from ten Saudi university students at the English Department, Faculty of Sciences and Arts in Almandag during the first semester of 2020- 2021. The researcher used the descriptive statistical method, which is a method that analyses, describes, and organizes the collected data in different graphs, tables, and charts. In this study, the researcher used a written test to collect the data, which were then analyzed via SPSS. The researcher corrected the students' tests worksheets, each correct answer got two marks in both part 1 and 2. The total of part1 is 100 marks and part 2 too. The following section describes the results of the data collection.

\section{RESULTS AND DISCUSSION}

\section{Verbs Follow by Certain Prepositions Results}

The researcher selected 50 verbs and asked the students to write down the correct prepositions that follow them. Table 3 below presents the students' results for four prepositions, namely 'in', 'on', 'at' and 'of'. Five verbs, trust, specialize, involve, implicate, and succeeded, were examined in relation to 'in'. As can be seen in the table, $1.6 \%$ of the students provided correct answers for the preposition 'in', which means that $16.0 \%$ and $8.4 \%$ provided incorrect answers, thus accounting for $84.0 \%$ of the total answers. The following five verbs were examined in relation to the preposition 'on': decide, congratulate, keen, base and concentrate. As Table 3 shows, $1.4 \%$ of the students provided correct answers, which means that $14.0 \%$ and $8.6 \%$ of the students provided incorrect answers, thus indicating that $86.0 \%$ of the total answers were incorrect. The third preposition was 'at'; as shown in the table, $2.4 \%$ of the students provided accurate answers, which means that $24.0 \%$ of the total answers were correct; however, $7.6 \%$ provided incorrect answers, which means that $76.0 \%$ of the total answers were incorrect. The last preposition was 'of'; as can be seen in the table, $1.8 \%$ of the students' answers were correct, accounting for $18.0 \%$ correct answers, and $8.2 \%$ of the students accounted for $82.0 \%$ of the incorrect answers. The total results for all the previous prepositions were $18.0 \%$ correct and $82.0 \%$ incorrect answers (see Figure 1).

Three prepositions were examined in Table 4, namely 'for', 'from' and 'about'. The preposition 'for' scored $24.0 \%$ correct answers, accounting for $2.4 \%$ of the total students' answers, while $76.0 \%$ of the answers were incorrect; this accounts for $7.6 \%$ of the total number of students. The second preposition examined in this group was 'from', which received $22.0 \%$ correct answers, accounting for $2.2 \%$ of the total answers, while $78.0 \%$ answers were incorrect, accounting for $7.8 \%$ of the total answers. The last preposition in this part was 'about', for which $6.0 \%$ answers were correct; this represents $0.6 \%$ of the students. However, $94.0 \%$ of the answers were incorrect, representing $9.4 \%$ of the total answers (see Table 4). Regarding the overall results for all three prepositions, $6.0 \%$ of the answers were correct and $94.0 \%$ were incorrect, as shown in Figure 1 below.

TABLE $3 \mid$ Results for the Prepositions in, on, at and of

\begin{tabular}{ccccccccc}
\hline Options & in & \multicolumn{2}{c}{ on } & \multicolumn{2}{c}{ at } & of \\
Correct & 1.6 & 16 & 1.4 & 14 & 2.4 & 24 & 1.8 & 18 \\
Wrong & 8.4 & 84 & 8.6 & 86 & 7.6 & 76 & 8.2 & 82 \\
Total & 10 & 100 & 10 & 100 & 10 & 100 & 10 & 100 \\
\hline
\end{tabular}

The following table 5 contained the last three prepositions tested in this study. They were into, with, and to. The first preposition into scored $28.0 \%$ correct answers, this result means $2.8 \%$ of the total result, and $72.0 \%$ were wrong answers, this shows $7.2 \%$ were wrong answers. The second prepositions which targeted $12.0 \%$ were correct answers, this indicates $1.2 \%$ of the total result and $88.0 \%$ were wrong answers, which represents $8.8 \%$ were wrong answers of the total students' number. The last preposition in this part was to which scored $24.0 \%$ were correct answers, this denotes $2.4 \%$ for the total students' number and $76.0 \%$ were wrong answers, this means, $7.6 \%$ of the total students. 
Overall, of these three prepositions were $24.0 \%$ correct answers, and $76.0 \%$ were wrong answers.
See table 3 below for details and figure 1 for more details.

TABLE $4 \mid$ Results for the Prepositions for, from and about

\begin{tabular}{ccccccc}
\hline Options & for & \multicolumn{2}{c}{ from } & \multicolumn{2}{c}{ about } \\
& Student's No & $\%$ & Student's No & $\%$ & Student No & $\%$ \\
Correct & 2.4 & 24 & 2.2 & 22 & 0.6 & 6 \\
Wrong & 7.6 & 76 & 7.8 & 78 & 9.4 & 94 \\
Total & 10 & 100 & 10 & 100 & 10 & 100 \\
\hline
\end{tabular}

TABLE 5 | Results for the Prepositions into, with and to

\begin{tabular}{|c|c|c|c|c|c|c|}
\hline \multirow{2}{*}{ Options } & \multicolumn{2}{|c|}{ into } & \multicolumn{2}{|c|}{ with } & \multicolumn{2}{|l|}{ to } \\
\hline & Student's No & $\%$ & Student's No & $\%$ & Student No & $\%$ \\
\hline Correct & 2.8 & 28 & 1.2 & 12 & 2.4 & 24 \\
\hline Wrong & 7.2 & 72 & 8.8 & 88 & 7.6 & 76 \\
\hline Total & 10 & 100 & 10 & 100 & 10 & 100 \\
\hline
\end{tabular}

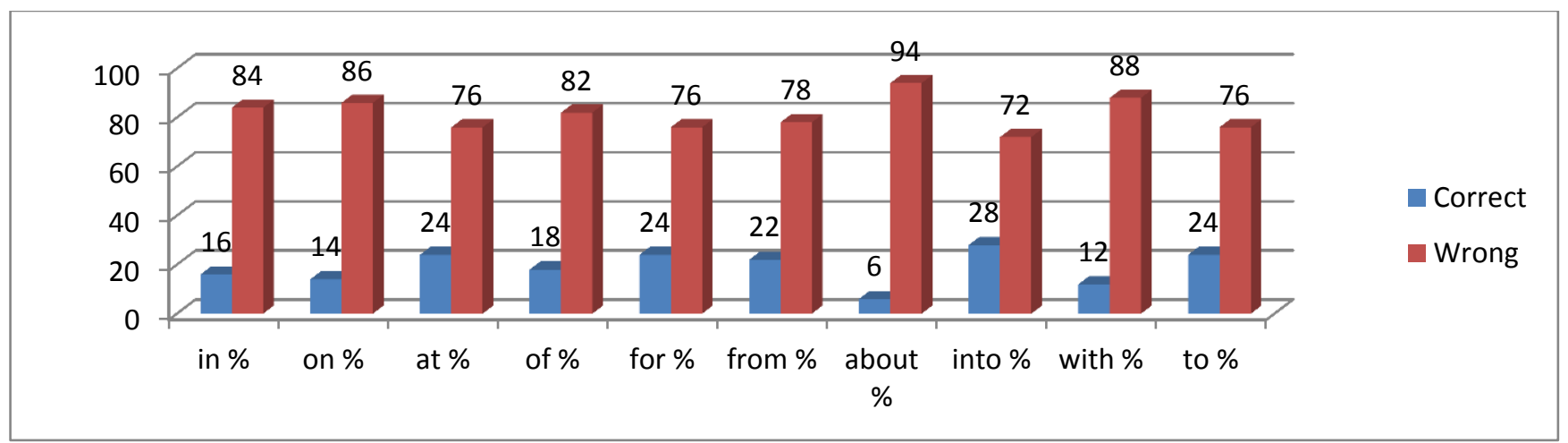

FIGURE 1 The Total Results for Ten Prepositions (in, on, at, of, for, from, about, into, with and to) that Follow Certain Verbs

\section{Results for the Prepositional Phrases}

The Saudi students' use of prepositional phrases using ten prepositions in this part. As shown in Table 6, the first prepositional phrase, 'in', received $3.0 \%$ correct answers, thus accounting for $30.0 \%$ of the correct answers. However, $7.0 \%$ of the students' answers were incorrect, which indicates that $70.0 \%$ of the students' answers were incorrect. The prepositional phrase including 'on' received $1.2 \%$ correct answers, meaning that $12.0 \%$ of the students answered correctly. However, the score for incorrect answers was $8.8 \%$, which indicates that $88.0 \%$ of the students' answers were incorrect. The prepositional phrase including 'at' received $0.4 \%$ correct answers, which indicates that $4.0 \%$ of the answers were correct. However, the score for incorrect answers was $9.6 \%$, which means that $96.0 \%$ of the answers were incorrect. The prepositional phrase including 'for' received $2.2 \%$ correct answers, which indicates that $22.0 \%$ of the answers were correct. However, $7.8 \%$ of the answers were incorrect, which means that $78.0 \%$ of the students provided incorrect answers. Overall, the results for these four prepositions were $22.0 \%$ correct and $78.0 \%$ incorrect answers. See Table 6 for more information.
The next table presents three prepositions that were tested in combination with the prepositional phrases; the prepositions were 'for', 'from' and 'about'. As can be seen in Table 7, the first prepositional phrase included 'for', and received $1.4 \%$ of the correct answers, thus accounting for $14.0 \%$ of the total responses. The second prepositional phrase included 'from', and the results were as follows: $1.4 \%$ of the students provided correct answers, which indicates that $14.0 \%$ of the answers were correct. However, $8.6 \%$ of the students provided incorrect answers, which means that $86.0 \%$ of the students' answers were incorrect. The last prepositional phrase included 'about', and accounted for $2.8 \%$ of the correct answers, which indicates that $28 \%$ of the students' answers were correct. However, $7.2 \%$ of the students' answers were incorrect, which means that $72.0 \%$ of the students selected incorrect answers. See Table 7 below for more details. 
TABLE 6 | Percentages for the Prepositional Phrases including in, on, at and for

\begin{tabular}{ccccccccc}
\hline Options & in & \multicolumn{2}{c}{ on } & \multicolumn{2}{c}{ at } & \multicolumn{2}{c}{ of } \\
& Student's No & $\%$ & Student's No & $\%$ & Student's No & \% & Student's No & $\%$ \\
Correct & 3 & 30 & 1.2 & 12 & 0.4 & 4 & 2.2 & 22 \\
Wrong & 7 & 70 & 8.8 & 88 & 9.6 & 96 & 7.8 & 78 \\
Total & 10 & 100 & 10 & 100 & 10 & 100 & 10 & 100 \\
\hline
\end{tabular}

TABLE $7 \mid$ The Second Group of Prepositional Phrases, which included for, from and about

\begin{tabular}{|c|c|c|c|c|c|c|}
\hline \multirow[b]{2}{*}{ Options } & \multicolumn{2}{|c|}{ for } & \multicolumn{2}{|c|}{ from } & \multicolumn{2}{|c|}{ about } \\
\hline & $\begin{array}{c}\text { Student's } \\
\text { No }\end{array}$ & $\%$ & Student's No & $\%$ & Student's No & $\%$ \\
\hline Correct & 1.4 & 14 & 1.4 & 14 & 2.8 & 28 \\
\hline Wrong & 8.6 & 86 & 8.6 & 86 & 7.2 & 72 \\
\hline Total & 10 & 100 & 10 & 100 & 10 & 100 \\
\hline
\end{tabular}

The third group included the prepositional phrases 'into', 'with' and 'to'. For the prepositional phrase that included 'into', $0.8 \%$ of the students provided correct answers, which indicates that $8.0 \%$ of the students' answers were correct. However, $9.2 \%$ of the answers were incorrect, which means that $92.0 \%$ of the students provided incorrect answers. For the second prepositional phrase, which included 'with', $2.0 \%$ of the students provided correct answers, which indicates that $20.0 \%$ of the total answers were correct.
However, $8.0 \%$ of the students provided incorrect answers, which represents $88.0 \%$ of the total answers. The last prepositional phrase included 'to'; $1.6 \%$ of the students provided correct answers, accounting for $16.0 \%$ of the total answers. However, $8.4 \%$ of the students provided incorrect answers, which means that $84.0 \%$ of the students' answers were incorrect. Table 8 shows the results for the prepositional phrases that included 'into', 'with' and 'to'. The general results for all the prepositional phrases are presented in Figure 2 below.

TABLE 8 | The Third Group of Prepositional Phrases, which included into, with and to

\begin{tabular}{ccccccc}
\hline Options & \multicolumn{2}{c}{ into } & \multicolumn{2}{c}{ with } & \multicolumn{2}{c}{ to } \\
Correct & Student's No & $\%$ & Student's No & $\%$ & Student's No & $\%$ \\
Wrong & 8 & 8 & 2 & 20 & 1.6 & 16 \\
Total & 9.2 & 92 & 10 & 100 & 8.4 & 84 \\
\hline
\end{tabular}

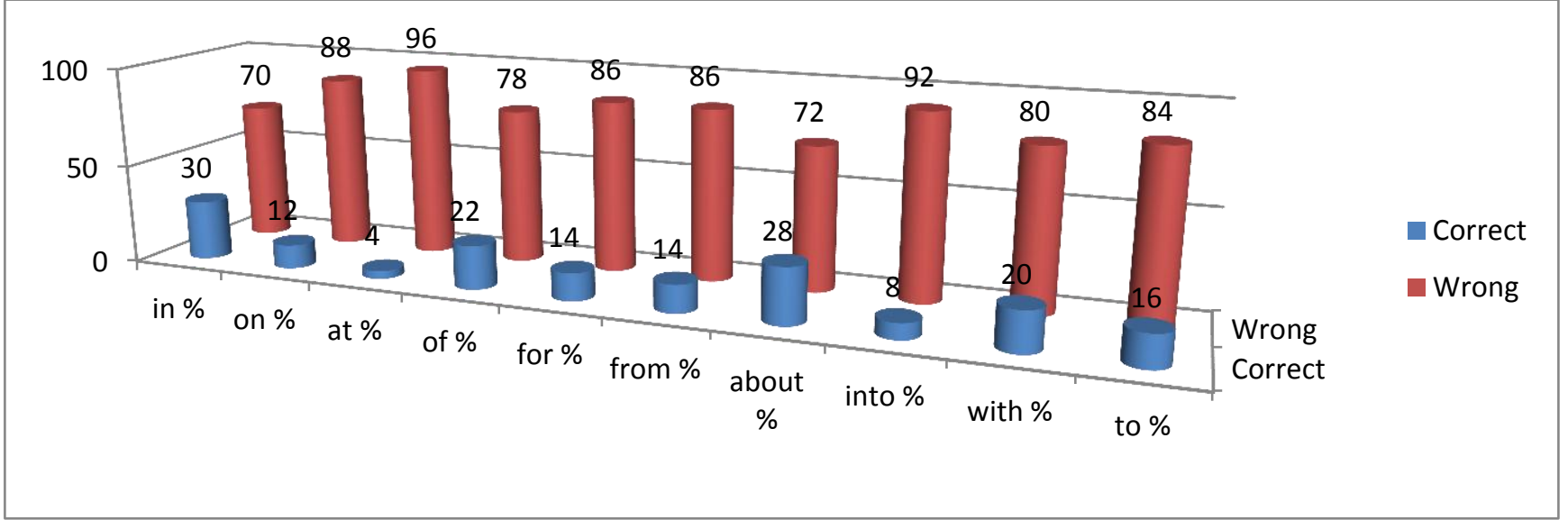

FIGURE 2 The total results for the ten prepositional phrases that included in, on, at, for, by, under, out of, from, without and to

The first hypothesis in this study was that Saudi students as EFL can identify the appropriate prepositions to use after certain verbs. To test this hypothesis, ten prepositions were chosen and divided into three groups. 
The students were given 50 verbs and were asked to provide the prepositions that followed them. The first group included four prepositions, namely 'in', 'on', 'at' and 'of'. The results were as follows: The preposition 'in' that was to be matched to the words trust, specialize, involve, implicate, and succeed received $30.0 \%$ incorrect and $70.0 \%$ correct answers. The second preposition, 'on', was tested in combination with the following words: decide, congratulate, keen, base and concentrate, resulting in $12.0 \%$ incorrect and $88.0 \%$ correct answers. The third preposition, 'at', was tested in combination with the following words: smile, laugh, stare, peer, and point, and received $4.0 \%$ correct and 96.0\% incorrect answers. The last preposition in this group was 'of', which was tested in combination with consist, think, remind, convict, and accuse; the result was $22.0 \%$ correct and $78.0 \%$ incorrect answers.

The second group included the prepositions 'for', 'from' and 'about'. The results were as follows: The preposition 'for' received $14.0 \%$ correct and $86.0 \%$ incorrect answers, while the preposition 'from' received $14.0 \%$ correct and $86.0 \%$ incorrect answers. The last preposition, 'about', received $28.0 \%$ correct and $72.0 \%$ incorrect answers. The third group included 'into', 'with' and 'to'. The results were as follows: The preposition 'into' received $8.0 \%$ correct and $92.0 \%$ incorrect answers, while the preposition 'with' received $20.0 \%$ correct and $80.0 \%$ incorrect answers. The last preposition in this group was 'to', which received $16.0 \%$ correct and $84.0 \%$ incorrect answers. The overall result for the first hypothesis was that Saudi students in the English department failed to achieve the target score of 50 marks in all three groups examined. These results indicate that the Saudi students could not identify which prepositions to use after certain verbs; hence, the first hypothesis was not supported.

The second hypothesis was that Saudi students as EFL use English prepositional phrases correctly. The study investigated three groups of phrases; the first group included 'in', 'on', 'at' and 'for'. The results were as follows: 'in' received $30.0 \%$ correct and $70.0 \%$ incorrect answers, while 'on' received $12.0 \%$ correct and $88.0 \%$ incorrect answers. The preposition 'at' received $4.0 \%$ correct and $96.0 \%$ incorrect answers, and the last preposition in this part, 'for', received $22.0 \%$ correct and $78.0 \%$ incorrect answers. The second group included the 'for', 'from' and 'about', and the results were as follows: 'for' received $14.0 \%$ correct and $86.0 \%$ incorrect answers, 'from' received $14.0 \%$ correct and $86.0 \%$ incorrect answers, and the last preposition in this part, 'about', received $28.0 \%$ correct and $72.0 \%$ incorrect answers. The last group of prepositional phrases included 'into', 'with' and 'to'. The preposition 'into' received 8.0\% correct and 92.0\% incorrect answers, the preposition 'with' received $20.0 \%$ correct and $80.0 \%$ incorrect answers, and the last preposition, 'to', received $16.0 \%$ correct and $84.0 \%$ incorrect answers. In summary, the students' scores for the three groups were all below 50 marks. These results indicate that the Saudi students did not use the English prepositional phrases correctly; hence, the second hypothesis was not supported.

In this study the researcher investigated ten prepositions, the first group were in, on, at and of. Their final scored as follow; the preposition in $30.0 \%$ correct and $70.0 \%$ were wrong answers. The preposition on $12.0 \% \%$ correct and $88.0 \%$ wrong answers. Also, at scored $4.0 \%$ correct and $96.0 \%$ wrong answers. The last preposition in this group was of the final scored $22.0 \%$ correct and $78.0 \%$ wrong answers. The first problem that faced Saudi students in this study, English and Arabic Prepositions are different in number and their structure. Also, prepositions in both languages do not have certain meaning and usage. This agrees with (Alwreikat \& Yunus, 2020) stated "in process of learning English preposition, Jordanian EFL learners justifiably attempt to relate them to the lesser number of Arabic prepositions and to Arabic structure. Therefore, the first problem for these learners lies in the point that not every Arabic preposition has a fixed equal in English and vice versa, secondly, not every preposition in both English and Arabic has a fixed usage and meaning, demonstrating time or space."

The second group in this study was three prepositions: for, from and about. The preposition for scored 14.0\% correct and $86.0 \%$ wrong answers, and from scored $14.0 \%$ correct and $86.0 \%$ wrong answers. The last preposition in this group was about which scored $28.0 \%$ correct and $72.0 \%$ wrong answers. By looking to the overall results, the students faced this problem due to some prepositions do not exist, or do not have equivalent in their (L1). But other prepositions may have. This point agrees with (Almahammed, 2016) he arrived at the result that "English language prepositions can be grouped as complex prepositions which do not exist or have equivalent in Arabic or one-word prepositions (simple prepositions) that might have an equivalent in Arabic. It is important to mention that many prepositions in English language cannot be treated as prepositions in Arabic". Also, one of the problems that experienced students that English prepositions have different meaning, and this depend on the context. As Lornicz and Gorden (2012) indicated that "there are several factors why English prepositions are found to be difficult for learners of English. First, English prepositions are "polysemous" which means that a lot of them can have a variety of meanings depending on context".

In the third group three was prepositions into, with, and to. The preposition into scored $8.0 \%$ correct and $92.0 \%$ wrong answer. Also, preposition with recorded $8.0 \%$ correct and $92.0 \%$ wrong answers. The last preposition in this group 
was to which gained $16.0 \%$ correct answer and $84.0 \%$ wrong answer. Using and mastering preposition in the daily life conversation is a problem to some Saudi university students. Because some prepositions do not have certain rules and functions too. This point relied by the researcher,

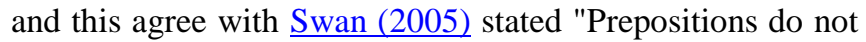
accept new words easily, but they have notoriously polysemous behaviors in sentences. They are difficult to learn as most of them have different functions and they do not have many rules to help in choosing the right prepositions in a particular context". They combine with other parts of speech to express new meanings, and they participate in idiomatic expressions.

To conclude, by looking to the results of all these prepositions, this study answered the study's questions; do Saudi students as EFL use prepositions after certain verbs accurately? And do Saudi students as EFL use prepositional phrases correctly? In addition, it approved the hypotheses too. Saudi students as EFL can identify the appropriate prepositions to use after certain verbs. And Saudi students as EFL use English prepositional phrases correctly.

\section{CONCLUSION}

In conclusion, this study aimed to shed light on Saudi university students' problems with using correct English prepositions. This problem faced some students in their writing and communication at faculty of Sciences and Arts in Almandag. The study reviewed the shortcomings the use of English prepositions based on the students' results and revealed that Saudi university students experienced problems with the correct use of English prepositions following by certain verbs and in the use of prepositional phrases. The study also answered the main research questions in this study.

Based on the results and conclusions of this study, the following recommendations are suggested: Students need to revise the use of English prepositions in general. They need more practice in using prepositions after certain verbs. Students need to focus more on including English prepositional phrases in their written work. Regarding writing courses, students need more lessons that focus on the general and specific uses of prepositions. Curriculum designers need more attention about teaching prepositions in their textbooks and curriculums.

The researcher suggests the following topics for future research: To what extent can EFL curricula solve the problems pertaining to the correct use of English prepositions? The importance of accurate prepositional use in writing. To what extent can the correct use of English prepositional phrases assist students to improve their writing skills and communicative abilities?

\section{ACKNOWLEDGEMENTS}

The researcher would like to thank all students who contributed to this work.

\section{REFERENCES}

Al-Aidroos, N., Fischer, M. H., Adam, J. J., \& Pratt, J. (2008). Structured perceptual arrays and the modulation of Fitts's law: examining saccadic eye movements. Journal of motor behavior, 40(2), 155164.

Almahammad, Y. (2016) First Language transfer in the acquisition of English Prepositions by Jordanian EFL learners. Unpublished Ph.D. Thesis. (p.38).

Alwreikat, E. A., \& Yunus, K. B. (2020). Conventional errors in employing English prepositions in the written work of EFL Jordanian students. International Journal of Academic Research in Business and Social Sciences, 10(3), 488-496.

Al-Yaari, S. A. S., Al Hammadi, F. S., \& Alyami, S. A. (2013). Oral grammatical errors of Arabic as Second Language (ASL) learners: An applied linguistic approach. International Journal of English Language Education, 1(2).

Biber, D. (2003). 17 Compressed noun-phrase structures in newspaper discourse. New Media Language, 169.

Castro, M. C. S. A. (2013). An analysis of prepositional errors of college students. In Proceedings of the 3rd International Conference on Foreign Language Learning and Teaching: 97-108.

Choudhury, A. S. \& PGCTE, P. (2013). Of speaking, writing, and developing writing skills in English. Language in India, 13(9), 27-32.

Cowan, E. (1982). Writing. Brief edition Scott, Foresman and Company. U.S.A. (p.281).

Douglas Biber, S. C. (2003). Student grammar of spoken and written English England: Longman.

Elkhadiri, Y., \& Khouya, Y. B. Investigating learners' competence in the acquisition of English spatial prepositions: The case of Moroccan EFL 3rd Year University Students.

Herdi, H., \& Andriana, N. (2017). A study on the students' ability in using preposition of direction. ELTLectura, 4(2), 70-77.

Huddleston, R. (1984). Introduction to the grammar of English. Cambridge: (p.38). Cambridge University Press. (p.336).

Ibrahim, A. A. M. (2017). The difficulties encounter (ESP) students in using English prepositions of time. International Journal of Humanities Social Sciences and Education (IJHSSE), 4(11), 214-222.

John E.\& Earriner, M. E. (1958). English grammar and composition. United States: Harcourt. (P.211).

Kofi E. 2010. Applied English Syntax: Foundations for word, phrase, and sentence analysis. Dubuque, Iowa: Kendall Hunt Publishing Company. (p.297).

Lindstomberg, S. (1996) Prepositions: Meaning and methods. ELT Journal. 50(3), (p 225-236). 
Lorincs, K and Gordon. R. (2012) 'Difficulties in learning prepositions and possible solutions. Linguistics Potfolio. (p.1-14).

Randolph Quirk, and Sidney Greenbaum, Geoffrey Leech, and Jan Svartvik. (1985) A comprehensive grammar of the English Language. London: Longman. (p.673).

Riyanto, S. and N. (2012). A handbook of English grammar: An effective way to master English. Yogyakarta: Pustaka Pelajar. (P.167).

Seaton, A., \& Mew, Y. H. (2007). Basic English grammar for English language learners: Book 1. Three Watson, CA: Saddleback Educational Publishing, Inc. (p.132).

Stageberg, N. C. (1981). An introductory English Grammar. Fort Worth: Holt, Rinehart and Winston, Inc. (p.169).

Swan, M. (2005). Practical English usage. Oxford University Press. (P. 425).

Walker, B.L. (1982). Basic English Grammar. Baltimore, Maryland. USA. (p.123).

Warriner, J. E. (1958). English grammar and composition. [Grade]: Chapters on speaking and listening and parliamentary procedure. Harcout, Brace.

Wishon, G., \& Burks, J. (1980). Let's Write English. New York: American Book Company. (p.285).

Wren. P. C. \& Martin. H. (1999). High School English Grammar. S. Chand \& company LTD: New Delhi.

Yates, J. (1999), The ins and outs of prepositions, New York Barron's Educational Series. (p.5).

Conflict of Interest Statement: The authors declare that the research was conducted in the absence of any commercial or financial relationships that could be construed as a potential conflict of interest.

Copyright (C) 2021 Ibrahim Abdalla. This is an open-access article distributed under the terms of the Creative Commons Attribution License (CC BY). The use, distribution or reproduction in other forums is permitted, provided the original author(s) and the copyright owner(s) are credited and that the original publication in this journal is cited, in accordance with accepted academic practice. No use, distribution or reproduction is permitted which does not comply with these terms. 


\section{APPENDIX 1}

This test is designed to achieve the goals of this study: Difficulties of using Correct English Prepositions among Saudi EFL Students at Albaha University. The test divided into two parts.

Part one: verbs follow by certain prepositions.

Write the correct preposition in front of the following verbs

\begin{tabular}{|c|c|c|c|c|}
\hline recover & 2- cut & 3-decide & 4-pray ___ & 5- split \\
\hline 6- contribute & 7-trust_ & 8-fight__ & 9- consist & 10- care \\
\hline 11-congratulate & 12- feed up & 13- speak & 14- worry & 15- keen \\
\hline 16- think & 17- wait & 18- protect & 19- belong _ & 20-associate \\
\hline 21-escape & 22- forget & 23- remind & 24-base & 25- wish \\
\hline 26-specialise & 27- break & 28-scold & 29-invlove & 30- stem \\
\hline 31- smile & 32-laugh & 33-reply & 34-quarrel & 35-implicate \\
\hline 36- cover & 37-convict & 38-stare & 39- crash & 40-divide \\
\hline 41-accuse & 42- peer & 43-concentrate & 44- vote & 45-differ \\
\hline 46-successed & 47- listen & 48- agree & 49- point & 50- dream \\
\hline
\end{tabular}

Part one model answers

\begin{tabular}{|c|c|c|c|c|c|c|c|c|c|}
\hline in & on & at & of & for & from & about & into & with & to \\
\hline 7- $26-29$ & $3-11-$ & $31-42-32$ & $16-41-$ & $17-28$ & $1-21$ & $22-34$ & $2-27$ & $12-8$ & $6-47$ \\
\hline $35-46$ & 15 & $49-38$ & $37-23$ & $44-4$ & $18-30$ & $14-10$ & $39-5$ & $36-48$ & $13-33$ \\
\hline & $24-43$ & & 9 & 25 & 45 & 50 & 40 & 20 & 19 \\
\hline
\end{tabular}




\section{Part two}

Write the correct prepositional phrase in the following.

\begin{tabular}{|c|c|c|c|c|}
\hline $1-\ldots$ least & 2- ___ purpose & 3-___ regulation & 4- & 5-___ of breath \\
\hline $6-\ldots$ stress & 7-___ fear of & 8- ___ break & $\begin{array}{l}\text { the age of } \\
9 \text {-_experience }\end{array}$ & $10-$ __ the \\
\hline $11-\_$real & $12-\ldots$ the best of & $13-\ldots$ sea & 14- ___memory & $\begin{array}{l}\text { horizon } \\
15-\_ \text {date }\end{array}$ \\
\hline 16- ___ the north & 17- ___ now on & 18-___approval & 19-___ accident & $20-\ldots$ midnight \\
\hline $21-$ & 22-____demand & 23- ___ the & $24-$ & $25-$ \\
\hline doubt & & purpose & duty & suspicion \\
\hline $26-$ & $27-\ldots$ ship & 28-__ love & $29-$ & $30-$ __ the \\
\hline delay & & & time to time & extent of \\
\hline $31-\ldots$ foot & $32-$ & $33-$ & $34-$ & $35-$ \\
\hline & advance & presure & ahurry & hire \\
\hline 36-____ control & $37-$ & $38-$ & $39-$ & $40-$ \\
\hline $41-\ldots$ the & $\begin{array}{l}\text { exception } \\
42-\text { heat }\end{array}$ & $\begin{array}{l}\text { the agenda } \\
43 \text { date }\end{array}$ & $\begin{array}{l}\text { top to bottom } \\
44-\end{array}$ & $\begin{array}{l}\text { foundation } \\
45-\end{array}$ \\
\hline $\begin{array}{l}\text { ordinary } \\
46-\_ \text {luck }\end{array}$ & 47-___ chance & $48-\ldots$ risk & $\begin{array}{l}\text { difficult } \\
49-\end{array}$ & $\begin{array}{l}\text { amess } \\
50-\end{array}$ \\
\hline & & & treatment & certain \\
\hline
\end{tabular}

Part two model answers

\begin{tabular}{|c|c|c|c|c|c|c|c|c|c|}
\hline in & on & at & for & by & under & Out of & from & without & to \\
\hline $22-32$ & $31-10$ & $1-4-20$ & $11-28$ & $13-46$ & $3-6-33$ & $5-24$ & $9-14$ & $8-21-37$ & $12-15$ \\
\hline $34-44$ & $38-2$ & $42-48$ & $50-35$ & $19-47$ & $49-25$ & $43-41$ & $17-29$ & $26-40$ & $16-23$ \\
\hline 45 & 18 & & 7 & 27 & & 36 & 39 & & 30 \\
\hline
\end{tabular}

